

\section{Audience Reactions to the Different Aspects of Nollywood Movies}

\section{Uchenna Onuzulike}

\section{Introduction}

Video technology has revolutionized how Nigeria and other African countries make movies. The popularity of Nollywood video film as a cultural phenomenon has increased interest in Nigerian culture not only within Nigeria and other parts of Africa but also throughout the rest of the world (Abah 2008; Okome 2007; Onuzulike 2007a, 2007b). Nollywood critics have raised concerns about the quality of Nigerian movies (McLaughlin 2005) and the depiction of the supernatural (Eghagha 2007; McCall 2002). Contrarily, Nollywood has also been cast as an "extremely popular medium for a complete revisioning of the story of the people" (Okuyade 2011:1). Likewise, in Onuzulike's work on conceptualization of video film theory, he articulates that "video film as a tool of development communication has positioned Nollywood to help articulate Nigerian cultural heritage and Africa as a whole" (2015: 97). Nollywood can equally impact the narrative of the people positively or negatively.

Several studies have examined audience participation in Nollywood, including the attitude of the Nollywood audience toward its movies (Akpabio 2007); Nollywood in the context of spectatorship, audience and the location of consumption (Okome 2007); Nollywood movies and cultural imperialism (Akpabio \& Mustopha 2008); production practices and audience reactions to the movies (Esan 2008); the nostalgic feelings of the Yoruba diasporic population in London toward their culture (Detokunbo-Bello 2010); Nigerian Nollywood audiences online (Obiaya 2010); Nollywood audience perceptions of the movies (Agba \& Ineji 2011); audience reception of Benin-language Nollywood movies (Omoera 2014); the contributions of the Africa Magic 
audience, television, and the Nollywood audience toward the growth of the Nollywood film (Ekwuazi 2014); a Kenyan audience's perception of witchcraft in Nollywood movies (Waliaula 2014); and the assessment and the dominance of Nollywood movies as mirrored in Ugandan weekly TV programming (Dipio 2014). However, no prior study found has investigated how audience-member reactions vary according to whether the viewer is a Nigerian living within Nigeria or outside of Nigeria. This study is designed to fill the gap.

The purpose of the present study is to understand audience perceptions of different aspects of Nollywood movies, and to explore how these vary across Nigerians in Nigeria and Nigerians in South Africa. Literally, the favorite aspect is what the audience liked in Nollywood movies while the disliked aspect is what the audience disapproved of. The Nollywood filmmakers continue to make movies and impact Nigeria and other African societies as they produce movies during the constant evolvement of African cultures, which has impacted the audience reception“encoder/producer and decoder/receiver" (Hall 1980: 131).

\section{Reception Analysis}

This study is grounded in reception analysis in order to understand how Nollywood audiences in Nigeria and South Africa construct meaning based on Nollywood films offered by the filmmakers. Reception analysis also known as audience reception, which emerged in the $80 \mathrm{~s}$ (Hall 1980; Morley 1980; Ang 1985, 1989), denotes "how audiences construct meanings out of media offerings, generally called texts" (Ang 1995: 6). According to Ang, "the starting point here is the assumption that the meaning of media texts is not something fixed, or inherent within the text. Rather, media texts acquire meaning only at the moment of reception, that is, when they are read, viewed, listen to, and so on" (1995: 6). She elaborates that audiences are perceived "as 
producers of meaning, not just consumers of media content: They decode or interpret media texts in ways that are related to their social and cultural circumstances and to the ways in which they subjectively experience those circumstances" (1995: 6).

Ang (1995) acknowledged Radway's (1987) claim that some researchers adopt the term "interpretive communities" to imply groups of individuals who make shared interpretations of a text. Ang uses subcultures to support his assertion. According to Jandt:

A subculture resembles a culture in that it usually encompasses a relatively large number of people and represents the acculturation of generations of human striving. However, subcultures have some important differences. They exist within dominant cultures and are often based on economic or social class, ethnicity, or geographic region. (2013: 8)

In the case of this study, subcultures are based on nationality and geographic region. The nationality is Nigerian while the geographic region comprises both Nigeria and South Africa. It is certain that not all Nigerians interpret Nollywood films the same way. This is because there are many ethnicities, communities, and subgroups within Nigeria and within the group of Nigerians residing in South Africa.

As observed by reception analysis researchers, each group or community "will 'negotiate' the text [film] in ways that make sense within its own social and cultural situation" (Ang 1995: 7). Accordingly, reception researchers do not generally use the standard questionnaire as a method of investigation. Instead, they use more small-scale, qualitative methods, such as group interviews and in-depth individual interviews, in which they try to unravel the interpretations made of certain media content by a small group of viewers or readers. (Ang 1995: 7) 
This study perfectly fits this definition as it utilizes small-scale Nigerian samples in Nigeria and in South Africa to understand how meaning is constructed at the time of the reception of Nollywood movies, especially in relation to quality, folk culture, and the supernatural.

\section{Quality, Folk Culture, and the Supernatural}

Nollywood film has been gaining momentum on the global stage, yet there are concerns about the quality and cultural impact of the movies. By juxtaposing the cultural aspect and the quality of the movies in relation to the audience members, it is evidenced that some major concerns expressed about Nollywood pertain to the plots and quality of the movies. According to Faris, the quality of Nollywood movies is often sacrificed for quick turnover. He says "a typical Nigerian video is shot in two weeks and offers poor acting, unimaginative shots and volume jumps between cuts. But whether they feature cultists, armed robbers or just young girls searching for love in Lagos, the scripts always have local flavor" (2002: 39). In other words, the poor quality could negatively impact how Nollywood's different audiences perceive Nigeria, and, in general, African culture. This is explicated by Onuzulike's work on Nollywood in the context of media ecology. He articulates the following:

By applying McLuhan's hot-cool model to Nollywood video film ('secondary orality') productions, it is reasonable to conclude that viewers of Nollywood movies would be better off seeing the hastily made video films in the theatre (low in participation) than on home television (high in participation), because video films can be hot or cool depending on whether it is viewed on home television or in the theatre. The larger budget or celluloid productions could be viewed both on televisions at homes or in the theatre because they are more than likely to portray African cultures and environments in a positive way. (2014: 289) 
Onuzulike notes, "the popular quick and cheap productions are likely to lend Nollywood movie-makers and stakeholders to distort and romanticize African cultures and environments, as well as presenting them negatively" (2014: 289). In essence, "the content of the movies is compromised because the video film-makers may not be able to achieve a true portrayal of cultural history, or the intended messages to be conveyed in the film might be misconstrued" (2014: 286). Madichie and Nkamnebe (2010) identified poor acting and directing, as well as poor sound quality and lack of creativity, as drawbacks to the industry. Oguine (2004) adds that several foreign and local critics have condemned Nollywood for unoriginal plots, poor dialogue, and poor production values. The quality of the narrative is as vital to the audience as the narratives are essential because it keeps them abreast of their cultural heritage (Esan, 2008). When the quality of the narrative is poor, it can undermine and impact the culture of the people negatively. The portrayal of the supernatural remains the most debatable genre of Nollywood production.

According to John Mbiti (1991[1969]), religious overtones with implications of the supernatural are ingrained in many African folk cultures and are often present in Nigerian movies. He argues that religion is a key part of the cultural heritage and is by far the richest part of African heritage. Regarding the activities and depiction of the supernatural in Nigerian movies, some consider it as problematic and degrading while others see it as part of Nigerian indigenous culture. For example, Oguine (2004) argues that one of the most common Nollywood faults is that the industry focuses on "black magic" in its plots. He argues that movies depicting Nigerians as attached to supernatural forces give foreigners the idea that Nigerians are a backward people. On the other hand, R. Ohajianya (personal communication, March 7, 2006), the former chairman of the Actors' Guild of Nigeria, Lagos branch, argues that Nigerian movies portray the people's way of life in Nigeria. He notes, "As a filmmaker and as an actor you are the reflection of the society." 
Also, the Nigerian film industry has produced a number of movies that have something to do with witchcraft. Similarly, some Nollywood movies have explored themes such as magical realism (Eghagha 2007), Christianity and consumer influence (Ukah 2003). Oguine (2004) worries that the prevalence of witchcraft and violence in the movies may encourage beliefs in the worst stereotypes of Africans.

Even though this study was conducted in 2006, it remains relevant because no research to date has compared Nigerian responses to Nollywood movies depending upon the geographic location of the Nigerians. In addition, there are relatively scant studies of the Nollywood audience (Obiaya 2010; Okome 2007). An article by Ojukwu and Ezenandu “criticizes the industry's poor manner of exposing some African negative traditions and its inability to use some core shared values and norms to enhance, transform and consolidate the emerging African democracy" (2012: $25)$; and they urged the industry to shift from tradition to modernity in presenting African narratives. None of the previous studies has specifically examined how Nollywood audiences perceive different aspects of Nollywood movies. Therefore, the following two research questions were posed:

RQ1: What are the favorite aspects of Nollywood movies?

RQ2: What are the disliked aspects of Nollywood movies?

\section{Methodological Approach}

This qualitative study employs an open-ended approach that was utilized to permit participants to give attention to issues pertinent to them (van Manen 1990). The participants were from three different cities, making this a purposive sample that cannot be generalized. There are a total of 116 participants. They consist of 38 Nigerian students from the University of Nigeria 
Nsukka, and 78 Nigerians residing in Johannesburg (in Gauteng Province) and Durban (in KwaZulu-Natal Province), South Africa. The participants do not reflect the general population of Nigerians in Nigeria and South Africa. The respondents (especially those who are not literate) were (guided) as to how to answer the questions. The sample ages ranged from 18 to 45 years $(\mathrm{M}=92 \& \mathrm{~F}=24)$, and their occupations and education represented a distinct mix.

In order to analyze the data, the researcher employed Strauss and Corbin's (1998) procedure by dividing the responses into categories. First, the responses were read multiple times to generate initial themes through open coding; secondly, they were narrowed to subcategories via axial coding; and lastly the emergent categories were continuously developed, condensed, and advanced until they were discrete of the data through selective coding (Kassing \& Pappas 2007). Upon completion of the coding process, eight favorite aspects themes were generated, including: (1) culture, (2) morals/lessons, (3) humor, (4) reality, (5) quality, (6) no aspects, (7) wealth, and (8) the supernatural. For the disliked aspects, six themes emerged, including: (1) the supernatural, (2) no dislike, (3) quality, (4) piracy (5) repetition, and (6) romance.

\section{Findings}

Preliminary data were collected in order to explore initial questions related to Nollywood audience reactions and to different aspects of Nigerian movies. In this interpretative research, the aim is to reach an interior level of understanding of phenomenon instead of relying on a simple judgment for the answer. The findings are unique to particular things being investigated and cannot be generalized. Numerical information is utilized in these findings to show the power of various items in the sample for descriptive (and not statistical) purposes (Byerly 2009). 


\section{Favorite Aspects}

For Nigerians in Nigeria, the results revealed a close range of favorite aspects (see Table 1). The first choice was culture, which consisted of participants' assertions (e.g., "the way they dress," "culture, heritage, and values," and "traditional setting"). The second choice was reality (e.g., "real life and witchdoctor" and "they portray reality"). This is followed by quality (e.g., "send message across and good setting" and "storylines"), respectively. Others are the flamboyant exhibition of wealth (e.g., "exhibition of wealth"), humor (e.g., "keep me happy”), and morals/lessons.

The responses of Nigerians in South Africa showed some differences (see Table 1). The most prevalent theme for both the Nigerians inside and outside of Nigeria was culture. Some of the responses by the participants include "they teach us about the event of our communities," "natural setting," "colorful," "educative and show Nigerian culture," and "learn about our tradition." The second theme for the South Africa sample was humor (e.g., "hilarious' and 'comedy"). The third theme was morals and lessons, which consists of responses such as "help correct mistakes," "how to be a nice father," and "teach morals and exposing bad events." The fourth theme was quality (e.g., "great movies"). This may imply patronizing Nollywood movies despite any shortcomings, such as the poor qualities. Next, appreciation of the supernatural (e.g., "expose the secret and witches and occult people") was expressed" as well as no favorite. Lastly, a few respondents indicated the reality of the movies (e.g., "they seem real"). 
Table 1: Favorite Aspects

\begin{tabular}{|c|c|c|c|c|}
\hline \multirow{2}{*}{ Favorite Aspects } & \multicolumn{2}{|c|}{ Nigerians in Nigeria } & \multicolumn{2}{c|}{ Nigerians in South Africa } \\
\cline { 2 - 5 } & Number of Participants & Percent & $\begin{array}{c}\text { Number of } \\
\text { Participants }\end{array}$ & Percent \\
\hline Culture & 13 & $34.21 \%$ & 28 & $35.90 \%$ \\
\hline Morals/lessons & 1 & $2.63 \%$ & 13 & $16.67 \%$ \\
\hline Humor & 2 & $5.26 \%$ & 16 & $20.51 \%$ \\
\hline Reality & 9 & $23.68 \%$ & 2 & $2.56 \%$ \\
\hline Quality & 5 & $13.16 \%$ & 11 & $14.10 \%$ \\
\hline No favorite & 6 & $15.79 \%$ & 4 & $5.13 \%$ \\
\hline Wealth & 2 & $5.26 \%$ & -- & - \\
\hline The supernatural & -- & -- & 4 & $5.13 \%$ \\
\hline Total & $\mathbf{3 8}$ & $\mathbf{1 0 0 \%}$ & $\mathbf{7 8}$ & $\mathbf{1 0 0 \%}$ \\
\hline
\end{tabular}

\section{Disliked Aspects}

As for the disliked aspects of the participants in Nigeria (Nigerians in Nigeria and Nigerians in South Africa), the most prevalent dislike is the quality ("They waste a lot of time in the movies"). This is followed by repetition (e.g., "repetition of theme" and "predictable"), which also can be considered a part of as the quality issue. This is followed by piracy and by the supernatural (e.g., "voodoo") respectively. Lastly, romance (e.g., "Increased immoral and criminal movies are bad for kids" and "Romance movies should be reduced because of kids") and the remainder say no dislike (see Table 2).

The thing the Nigerians in South Africa disliked the most was quality (e.g., "too much commercializing of new movies," "they release too many per month," "the same actor/s, too long," "long presentation of characters," "a lot of irrelevant movies," "locality," and "the audio is 
erratic; it increases and decreases at will") closely followed by no dislike about the movies. Next is the supernatural with sentiments (such as "too much occult and witchcraft"), followed by romance (e.g., "too much romance and traditional stuff" and "the romance is fake"), and the theme repetition (e.g., "long presentation of characters"), which is part of quality (see Table 2).

Table 2: Disliked Aspects

\begin{tabular}{|l|c|c|c|c|}
\hline \multirow{2}{*}{ Disliked Aspects } & \multicolumn{2}{|c|}{ Nigerians In Nigeria } & \multicolumn{2}{c|}{ Nigerians in South Africa } \\
\cline { 2 - 5 } & Number of Participants & Percent & $\begin{array}{c}\text { Number of } \\
\text { Participants }\end{array}$ & Percent \\
\hline The supernatural & 3 & $7.89 \%$ & 18 & $23.08 \%$ \\
\hline No dislike & 1 & $2.63 \%$ & 26 & $33.33 \%$ \\
\hline Piracy & 5 & $13.16 \%$ & -- & -- \\
\hline Quality & 20 & $52.63 \%$ & 27 & $34.62 \%$ \\
\hline Repetition & 7 & $18.42 \%$ & 3 & $3.85 \%$ \\
\hline Romance & 2 & $5.26 \%$ & 4 & $5.13 \%$ \\
\hline Total & $\mathbf{3 8}$ & $\mathbf{1 0 0 . 0 0 \%}$ & $\mathbf{7 8}$ & $\mathbf{1 0 0 \%}$ \\
\hline
\end{tabular}

\section{Discussion}

The aim of this study was to capture the two Nollywood audiences' favorite aspects and disliked aspects of Nollywood movies. Through the lens of reception analysis, the findings indicate that geographic location of both audiences contributed to how they interpreted Nollywood movies. The findings indicate that participants both in Nigeria and South Africa viewed the cultural component of Nollywood films positively. Nigerians in Nigeria tended to like reality while Nigerians in South Africa did not but expressed a greater preference for comedy. The Nigerians in Nigeria disliked repetition in the movies, which could be considered part of quality issue, while 
those in South Africa were almost evenly split by their dislike for poor quality, their appreciation of the supernatural, or their expression of no dislike. For those living outside of Nigeria, nostalgia leads them to seek movies that allow them to escape into a Nigeria that never was.

Findings for the first research question, which offered insight into favorite aspects, indicated that participants' pride of seeing the exhibition of their cultural heritage is important to them. This research affirms that just like Nigerians in Nigeria, Nigerians in the Diaspora recognize the cultural identity in Nollywood movies (Esan 2008; Detokunbo-Bello 2010).

Another significant finding is reality in Nollywood movies. Ukah echoed characteristics of reality that are portrayed in Nollywood movies, namely "almost all aspects of Nigerian social, political, economic and religious life" (2003: 204). This statement indicates that reality is a significant theme in Nollywood movies. Nonetheless, there is a paradox in liking of culture, morals/lessons, and reality between the two audiences. The paradox is that even though Nigerians in South Africa appreciate the Nigerian culture and moral/lesson in Nollywood movies, the research data shows that they do not like reality. This could be because they do not believe that filmmakers make enough effort depicting the true nature of Nigerian culture. Also, since they reside in the Diaspora, they can perhaps be more apprehensive about portraying non-African cultures as Africans or depicting "old" traditions as current.

Findings from the second research question, which offered insight about disliked aspects of Nollywood movies in terms of repetition of storylines raised by Nigerians in Nigeria, are consistent with Esan's (2008) articulation that Nollywood audiences recognize the same inefficiency, including poor production and, of course, repetition of the themes; yet Nollywood audiences still support the movie industry. Faris (2002) notes that the quality has been sacrificed in favor of, for example, quick turnover, lack of money, and unprofessionalism. The finding is in 
line with Onuzulike's (2014) study on hot-cool media, which suggests that low-quality Nollywood movies are likely to negatively impact Nollywood audiences. He notes that it is better to watch Nollywood movies in a theater than at home because audiences are likely to critically decode the messages unlike when they are viewed at home. Arguably the production quality has improved over the years. Just like any new innovation, it goes through rough roads before it starts to stabilize.

Another disliked aspect for those living in South Africa was portrayal of the supernatural in Nollywood movies. This was a dominant theme during the early stage of Nollywood in the '90s (Okome 2001; McCall 2004; Haynes 2005). Also, the findings indicate that piracy is an issue to some audiences, which is consistent with (Larkin 2000; Grey 2003). According to Mackay (2009) of CNN, piracy pulls the industry back because about 50 percent of Nollywood video films' profits are lost to piracy. At the same time, she reported that Nigeria's National Film \& Video Censors Board (NFVCB) has expressed optimism that ongoing reconstruction and formalization will improve the industry, and that due to the depth of the industry, the Nigerian government may reduce piracy through regulation, incentives, and empowerment for Nollywood.

\section{Conclusion}

This study highlighted how two Nigerian audiences in Africa (those of Nigeria and South Africa) are impacted by the Nollywood movies in relation to favorite and disliked aspects of the movies. It shows that the geographical location of Nigerian audiences impacted the tastes and choices of their movies. Even though both Nigerians in Nigeria and in South Africa appreciate Nigerian culture, the latter account that the films do not represent true Nigerian culture. The significance of this study is that it informs the Nollywood filmmakers that they should try to depict the true Nigerian and African cultures as much as they can. Mirroring McLuhan's hot-cool model 
suggests that the quality of Nollywood movies impacts how the audiences decode the movies. Utilizing reception analysis supports that Nollywood audiences react upon the reception or viewing of Nollywood movies. Thus, additional research is encouraged in fostering the relationship between Nollywood and audiences with respect to preserving African cultures. Video technology has revolutionized how Nigeria and other African countries make movies.

\section{BIBLIOGRAPHY}

Abah, A. L. (2008), 'One step forward, two steps backward: African women in Nigerian videoFilm', Communication, Culture \& Critique, 1(4), 335-357.

Agba, J. \& Ineji, P. (2011), 'Audience perception of Nollywood films', LWATI: A Journal of Contemporary Research, 8(1), 259-271.

Akpabio, E. (2007), 'Attitude of audience members to Nollywood films', Nordic Journal of African Studies, 16(1), 90-100.

Akpabio, E., \& Mustapha-Lambeb, (2008), 'Nollywood films and the cultural imperialism Hypothesis', Perspectives on Global Development and Technology, 7, 259-270.

Ang, I. (1985), Watching Dallas: Soap Opera and the Melodramatic Imagination, New York, NY: Methuen.

Ang, I. (1989), 'Wanted: Audiences. On the politics of empirical audience studies', in E. Seiter, H. Borchers, G. Kreutzner, \& E. M. Warth (eds), Remote Control: Television Audiences and Cultural Power. London, England: Routledge.

Ang, I. (1995), 'The nature of the audience', in A. J. Downing, A. Mohammadi, \& A. SrebernyMohammadi (eds), Questioning the Media (1-11). Thousand Oaks, CA: Sage Publications. 
Byerly, C. M. (2009), 'Women, the economy and news: Analysis of the 2008 U.S. primary Coverage', St. John's Journal of Legal Commentary, 24(2), 387-402.

Detokunbo-Bello, A. (2010), 'Experience of diasporic Nigerians watching Nollywood films', London South Bank University, London. Retrieved from http://www2.lse.ac.uk/media@lse/events/MeCCSA/pdf/papers/DetokunboBello,\%20Experience\%20of\%20Diasporic\%20Nigerians-new $\% 20$ year\%20day.pdf

Dipio, D. (2014), 'Audience pleasure and Nollywood popularity in Uganda: An assessment', Journal of African Cinemas, 6(1), 85-108.

Eghagha, H. (2007), 'Magical realism and the "power" of Nollywood home video films', Film International, 5(4), 71-76.

Eghagha, H. (2014), 'The perception/reception of DSTV/multichoice's Africa magic channels by selected Nigerian audiences', Journal of African Cinemas, 6(1), 21-48.

Esan, O. (2008), 'Appreciating Nollywood: Audiences and Nigerian films', Journal of Audience $\&$ Reception Studies (special edition), 5(1), 1-23.

Grey, S., (2003), 'Nigeria on-screen "Nollywood" films popularity rising among émigrés', The Washington Post-Washington, D.C, p. E01.

Hall, S. (1980), 'Encoding/Decoding', in S. Hall, D. Hobson, A. Lowe, \& P. Willis (eds), Culture, Media, Language. London, England: Hutchinson.

Haynes, J. (2005), “'Nollywood”: What's in a name? Making African Movies', Retrieved from http://www.nollywood.net/Essays

Jandt, F. E. (2013), An Introduction to Intercultural Communication: Identities in Global Community $\left(7^{\text {th }}\right.$ edition$)$, Los Angeles, CA: Sage Publications.

Kassing, J.W., \& Pappas, M. E. (2007), “'Champions are built in the off season”: An exploration of high school coaches' memorable messages', The Journal of Human Communication: A Journal of the Pacific and Asian Communication Association, 10(4), 544-553. 
Kwabena-Essem, N. A. (2006), 'A new look at juju', Djembe Magazine. Retrieved from http://www.afgen.com/juju.html

Larkin, B. (2000), 'Hausa dramas and the rise of video culture in Nigeria', in J. Haynes (ed), Nigerian Video Films (pp. 209-241). Athens, OH: Ohio University Center for International Studies.

Mackay, M. (2009). Nollywood loses half of film profits to piracy, say producers. $C N N$

Entertainment. Retrieved from http://www.cnn.com/2009/SHOWBIZ/Movies/06/24/nollywood.piracy/

Madichie, N. O., \& Nkamnebe, A. D. (2010), '51 Iweka road (Onitsha, Nigeria): could this single African address redefine business cluster development?', World Review of Entrepreneurship, Management and Sustainable Development, 6(3), 229 - 243.

Mbiti, J. S. (1991[1969]). Introduction to African Religion, Oxford, England: Heinemann.

McCall, J. C. (2004), 'Nollywood confidential: The unlikely rise of Nigerian video film', Transition Magazine, 95, 98-109.

McCall, J. S. (2002), 'Madness, money, and movies: Watching a Nigerian popular video with the guidance of a native doctor', Africa Today, 49(3), 79-94.

McLaughlin, A. (2005), 'Africans, camera, action: "Nollywood" catches world's eye', The Christian Science Monitor World. Retrieved from http:/www.csmonitor.com/2005/1220/p01s02-woaf.html

Morley, D. (1980), The Nationwide Audience: Structure and Decoding, British Film Institute Television Monograph no. 11. London: British Film Institute.

Obi-Rapu, Chris [as Mordi, Victor] (1992), Living in Bondage (Igbo Language; subtitled in English), Nigeria: Nek Video Links. 
Obiaya, I. (2010), 'Nollywood on the Internet: A preliminary analysis of an online Nigerian video-film audience', Journal of African Media Studies, 2(3), 321-338.

Oguine, I. (2004), 'Nollywood looks to the future', New Internationalist. Retrieved from http://newint.org/columns/viewfrom/2004/10/01/nollywood/

Ojukwu, C. \& Ezenandu, P. E. (2012), 'A paradigm shift from tradition to modernity in Nollywood's projection of African narratives', Global Journal of Human Social Science, 12(5), $20-26$.

Okome, O. (2007), 'Nollywood: Spectatorship, audience and the sites of consumption', Postcolonial Text, 3(2), 1-21.

Okome, O. (2001), ‘The popular art of African video-film', NYFA Quarterly. Retrieved from http://www.nyfa.org/archive detail_q.asp?type $=3 \& q i d=45 \&$ fid $=6 \&$ year $=2001 \&$

Okuyade, O. (2011), 'Women and evangelical merchandising in the Nigerian filmic enterprise', Kemanusiaan: The Asian Journal of Humanities, 18(1), 1-14.

Omoera, O. S. (2014), 'Audience reception of the Benin language video film in Nollywood', Journal of African Cultural Studies, 26(1), 69-81.

Onuzulike, U. (2007a), 'The birth of Nollywood: The Nigerian movie industry', Black Camera, $22(1), 25-26$.

Onuzulike, U. (2007b), 'Nollywood: The influence of the Nigerian movie industry on African Culture', The Journal of Human Communication: A Journal of the Pacific and Asian Communication Association, 10(3), 231-242.

Onuzulike, U. (2014, in-print), 'Nollywood video film's impact on Nigerian and other African environments and cultures', Explorations in Media Ecology, 13(3\&4), 279-292.

CINEJ Cinema Journal: Audience Reactions to the Different Aspects of Nollywood Movies

Volume 5.2(2016) | ISSN 2158-8724 (online) ｜ DOI 10.5195/cinej.2016.137| http://cinej.pitt.edu 
Onuzulike, U. (2015), 'Video film theory: Situating Nollywood within communication

Development', in I. Ndolo \& C. Onwumechili (eds), Nigeria: Development Communication \& Interrogating the Field (pp. 83-101). Enugu, Nigeria: Rhyce Kerex Publishers.

Ukah, A. F. (2003), 'Advertising God: Nigerian Christian video-films and the power of consumer culture', Journal of Religion in Africa, 33(2), 203-231.

Waliaula, S. (2014), 'Active audiences of Nollywood video-films: An experience with a Bukusu audience community in Chwele market of Western Kenya', Journal of African Cinemas, 6(1), 7184. 